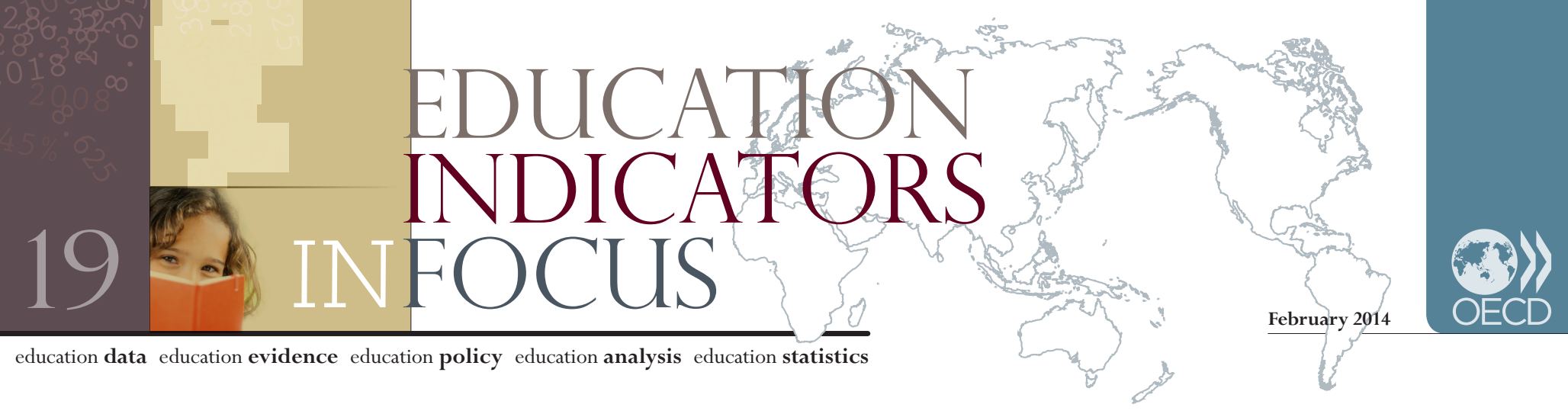

\title{
What are tertiary students choosing to study?
}

- The social sciences are the most popular field for non-vocational tertiary education programmes. One in three new students choose a programme in social sciences, business and law.

- Gender equality has been virtually achieved in many fields of study, especially in social sciences and services but significant gender differences persist in computing and engineering (maledominated) and in health and welfare and education (female-dominated).

- Almost one in four international students in OECD countries follow programmes in the field of business and administration (23\%). The proportion of international students from fields oriented to the public function such as education $(3 \%)$ or health and welfare $(9 \%)$ is lower on average.

Traditionally, high school graduates have placed a great deal of importance on the question "what field should I study and where?" There is a widespread assumption that this decision will determine their future and their job opportunities. Choosing a field of study means choosing a career, a professional identity, a sector of society, and to a certain extent also a way of life and a set of values. Yet there is no longer a straightforward relationship between the subject studied and future employment, as today's students have a variety of ways to acquire new skills and multiple paths to specialise in different domains. People change jobs and professions more frequently and job mobility is becoming an increasingly important feature of contemporary labour markets.

\section{ISCED Classification}

The International Standard Classification of Education (ISCED) by the UNESCO Institute for Statistics categorises fields of study in order to facilitate comparisons of education statistics and indicators on the basis of uniform and internationally agreed definitions. This classification comprises 25 narrow fields of education organised in 9 broad groups. General programmes (0) are not included in this analysis as these programmes are usually found at the lower levels of education. Please note that "social sciences" refers to the broad field (3) and not to the narrow field "social and behavioural sciences". "Science-related fields" here include both science (4) and engineering, manufacturing and construction (5) together.

Source: UNESCO-UIS, 2012.

\begin{tabular}{|c|c|}
\hline Broad fields & Narrow fields \\
\hline \multirow[t]{3}{*}{ 0) General programmes } & Basic programmes \\
\hline & Literacy and numeracy \\
\hline & Personal development \\
\hline 1) Education & Teacher training and education science \\
\hline \multirow[t]{2}{*}{ 2) Humanities and arts } & Arts \\
\hline & Humanities \\
\hline \multirow[t]{4}{*}{ 3) Social sciences, business and law } & Social and behavioural sciences \\
\hline & Journalism and information \\
\hline & Bussiness and administration \\
\hline & Law \\
\hline \multirow[t]{4}{*}{ 4) Science } & Life sciences \\
\hline & Physical sciences \\
\hline & Mathematics and statistics \\
\hline & Computing \\
\hline \multirow{3}{*}{$\begin{array}{l}\text { 5) Engineering, manufacturing } \\
\text { and construction }\end{array}$} & Engineering and engineering trades \\
\hline & Manufacturing and processing \\
\hline & Architecture and building \\
\hline \multirow[t]{2}{*}{ 6) Agriculture } & Agriculture, forestry and fishery \\
\hline & Veterinary \\
\hline \multirow[t]{2}{*}{ 7) Health and welfare } & Health \\
\hline & Social services \\
\hline \multirow[t]{4}{*}{ 8) Services } & Personal services \\
\hline & Transport services \\
\hline & Environmental protection \\
\hline & Security services \\
\hline
\end{tabular}




\section{Which fields are most popular?}

The field of social sciences, business and law attracts most OECD students entering tertiary education. On average, almost one-third (32\%) of new tertiary students across OECD countries enroll in a social sciences programme, more than double the proportion of new students in engineering, manufacturing and construction (15\%), which is the second most popular field at bachelor's level (see chart below). The social sciences are the most popular field of study in every OECD country except Finland and Korea, where engineering, manufacturing and construction are top, chosen by one in four students. In Belgium, by contrast, almost one in four students pursue studies in health and welfare, the highest share in this field in the OECD.

\section{Distribution of new entrants into tertiary type-A and type-B programmes, ${ }^{1}$ by field of education (2011)}

\begin{tabular}{|c|c|c|c|c|c|c|c|c|c|}
\hline 40 & & & & & & & & & \\
\hline $35 \diamond$ & & & & & & & & & \\
\hline 30 & & $\checkmark$ & $\diamond$ & $\Delta$ & & & & & \\
\hline 25 & & & & & $\checkmark$ & & & 0 & \\
\hline 20 & & & & $\Delta$ & & $\vartheta$ & $\diamond$ & 8 & \\
\hline $15^{\triangle}$ & 9 & 0 & & & 0 & 0 & $\bar{n}$ & & $M$ \\
\hline 108 & $\Delta$ & $\hat{M}$ & 8 & 8 & $\Delta$ & $\theta$ & 8 & $\square$ & $\Delta$ \\
\hline $5 \theta$ & & & 1 & & $\triangle$ & $\diamond$ & $\Delta$ & $\triangle$ & 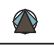 \\
\hline 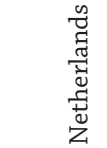 & 再 & $\begin{array}{l}\text { चี } \\
\text { त्ञ } \\
\text { م. }\end{array}$ & Оิ & 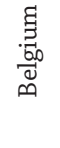 & $\begin{array}{l}\text {.ี } \\
\text { מี }\end{array}$ & 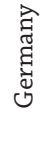 & 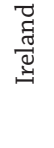 & 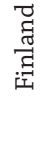 & 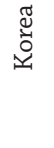 \\
\hline
\end{tabular}

Note: Only those fields with at least $5 \%$ of students are shown in this chart.

1. Tertiary type-A programmes are theory-based programmes whereas type-B programmes are more vocational. Countries are ranked in descending order of new entrants in social sciences, business and law programmes in 2011. Source: Education at a Glance 2013: OECD Indicators, Indicator C3 (www.oecd.org/edu/eag.htm).

At the other end of the scale, the least common fields are agriculture and services, with less than $10 \%$ of new tertiary students choosing these domains. However, the number of programmes on offer in these fields is normally smaller than in other fields. $\diamond$ Education

$\square$ Humanities and arts

$\triangle$ Health and welfare

$\diamond$ Social sciences, business and law

$\triangle$ Services

Engineering, manufacturing and construction O Science

— Not known or unspecified

\section{Are there still male-dominated and female-dominated fields in higher education?}

Gender imbalances still exist in certain fields. The distribution of students entering the sciences is quite uneven between men and women: only $14 \%$ of women choose to enter into tertiary education in a science programme, in contrast with 39\% of men. This difference does not seem related to performance differences, as the PISA 2012 data show that, on average across 65 countries, there are no significant differences between the performance of male and female students in sciences at 15 (OECD, 2013). Although this is not true for every single country that participated in PISA, it might be expected that, on average, boys and girls would complete upper secondary education equally prepared to study a bachelor's degree in science-related fields.

So why are women still under-represented in both sciences and the wider science-related fields? According to the PISA 2006 results, four times more 15-year-old boys (18.2\%) than girls (4.6\%) expressed an interest in developing their careers in the fields of engineering or computing or architecture by the age of 30 (OECD, 2007). 
Furthermore, the American Association of University Women (Hill et al., 2010) found that stereotypes and cultural factors can lower girls' aspirations for a career in sciences and engineering over time. These factors, it is argued by Hill et al., can play such a determining role that girls may assess their own mathematical abilities lower than do boys with similar mathematical achievements. Many countries are developing campaigns to convince female students to choose to study sciences.

\section{Proportion of tertiary graduates, by field of education and by gender in OECD countries (2011)}

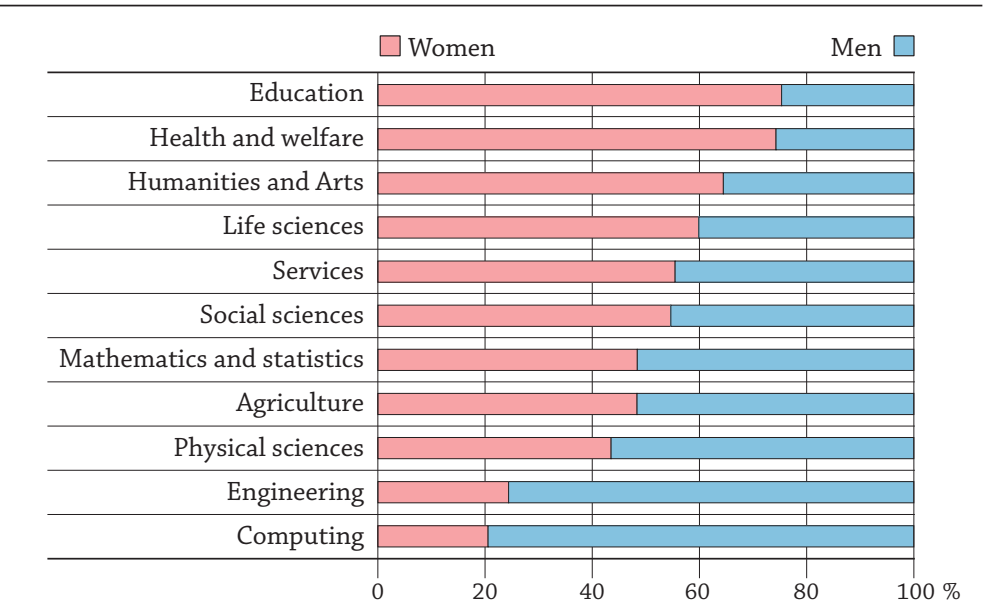

Note: In this chart, the broad field of science has been broken down into narrower fields such as physical sciences and mathematics in order to show the variation in the proportion of graduates, by gender within the field.

Source: Education at a Glance 2013: OECD Indicators, Indicator A3 (www.oecd.org/edu/eag.htm).
Unfortunately, women are also less likely to end up working in science-based occupations than men. Some $57 \%$ of female graduates in the fields of physics, mathematics and engineering get their first job in a different field from the one they studied (or they went into teaching) while only $30 \%$ of male graduates did (OECD, 2012).

As the chart on the left shows, in 2011 only one in five students who graduated in the fields of engineering or computing were women. In contrast, male graduates are similarly under-represented in the fields of education and health and welfare. Nonetheless, the gender gap has almost disappeared in several fields including services, social sciences, mathematics and statistics, agriculture and physical sciences.

\section{Which fields are most in demand among international students?}

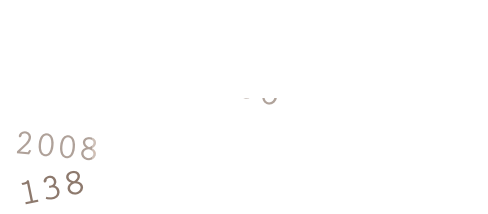

Studying abroad is not only a rewarding experience for any student, but also a distinguishing asset in the student's academic career. In certain disciplines it is very common to enroll in programme abroad, especially in business and administration. Roughly one in four international students in OECD countries (23\%) are enrolled in a business programme.

The United States, the United Kingdom, Australia, Germany and Japan are, respectively, the five OECD countries hosting the greatest number of international students (see the chart on page 4). As would be expected given its popularity among new entrants, the most popular field is social sciences, business and law. On average, $37 \%$ of OECD international students in tertiary education are enroled in this field. In Australia, these fields attract more than half (55\%) of incoming students, falling to roughly $27 \%$ in Germany. Germany also attracts a significant number of students to the areas of engineering (23\%), humanities and arts (20\%) and sciences (15\%). In none of these countries, and nor in the rest of OECD, are many international students pursuing studies in the fields of services and agriculture (with $6 \%$ and $2 \%$ of international students respectively on average).

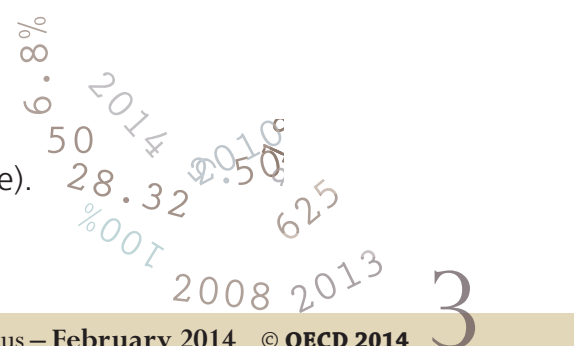


